UDK 664.784.8:598.296.4:636.085.52

\title{
PROPERTIES OF DIFFERENT SILAGE MAIZE HYBRIDS
}

Valentina V. Nikolić*, Slađana M. Žilić, Milica M. Radosavljević, Jelena P. Vančetović, Sofija S. Božinović

Maize Research Institute, Zemun Polje, Slobodana Bajića 1, 11085 Belgrade-Zemun, Serbia

\begin{abstract}
The aim of this study was to observe the properties of ten maize hybrids from Serbia including agronomic traits, lignocellulosic fibre composition and in vitro dry matter digestibility. Five yellow kernel dent hybrids and five analogue red kernel hybrids were used in this study to evaluate the agronomic traits, dry matter content of the whole plant, lignocellulosic fibre composition, ratios between different fibres, in vitro dry matter and NDF digestibility. Correlation coefficients between the investigated traits of the maize hybrids were assessed. Even though the results of our study showed variations regarding nutritional composition of the whole maize plant between the investigated maize hybrids, the hybrid and the differences in kernel colour (yellow or red) did not considerably affect the properties that influence quality of the maize hybrids for silage production. The highest IVDMD was determined in yellow kernel hybrid ZP 388, while the maximum NDFD was detected in the red kernel hybrid ZP $606_{\text {red }}$ which also showed the lowest $\mathrm{ADL} / \mathrm{NDF}$ and ADF/NDF ratios. The results indicate that all of the hybrids used in this study are good candidates for the production of high-quality silage for ruminant nutrition.
\end{abstract}

Key words: maize hybrids, lignocellulosic fibres, in vitro dry matter digestibility

\section{INTRODUCTION}

Maize (Zea mays L.) is considered as one of the most important cultivated crops and its production ranks as the third in the world after wheat (Triticum aestivum) and rice (Oryza sativa) (Liu et al., 2020). The first maize hybrid (double-cross inbred) was created in 1918 by D. F. Jones and later introduced experimentally in 1924 by H. A. Wallace, but it was not until 1933 that the farmers started using these modern seeds due to a long drought in rural parts of the USA (Sutch, 2011).

Conservation of forage maize by ensiling was first explored in second part of the nineteenth century, however, the major use of silage maize for cattle feeding began one hundred years later with the development of flint $\mathrm{x}$ dent hybrids tolerant to low temperatures (Barrière et al., 2018). Silage maize is currently one of the most important annual forage crops used in European dairy agriculture for ruminant nutrition (Barrière et al., 2018; Andersen et al., 2008). Silage maize is frequently used as a main source of energy in ruminant nutrition, is easy to produce and store and can be consumed daily throughout the year (Bertoia \& Aulicino 2014; Kruse et al., 2008).

The breeding of maize hybrids is crucial for high-quality silage production. It is based on combining achievements from the field of hybrid improvement for grain production with specific requirements for silage types of hybrids. The breeding of silage maize has re- 
cently been particularly focused on creating new hybrids with improved whole plant yield, nutritional quality parameters, and agronomic traits that ensure good ensiling properties, however, there has been a decrease in cell wall digestibility, and therefore the feeding value of the maize hybrids (Terzić et al., 2020; Milašinović et al., 2017; Andersen et al., 2008; Barrière et al., 2018). The nutritional value of maize intended for silage preparation is influenced by a number of factors such as genotype (maturity group, cell wall type, endosperm and starch type), agroecological conditions (soil type, fertilization, temperature, precipitation, etc.), maturity at harvest, harvesting method (chop length, kernel processing, etc.) as well as ensiling conditions (Khan et al., 2015).

Maize grain contributes to the overall silage maize quality by providing valuable nutrients for the animals. In average, maize kernel consists of $71.3 \%$ starch, $9.91 \%$ protein, $4.45 \%$ fat, $1.42 \%$ ash, and $2.66 \%$ crude fibre (Eckhoff \& Watson, 2009). Depending on the genetic background that affects the colour of the pericarp, aleurone, germ and endosperm, the colour of maize kernel can vary from white and yellow, through orange, red, burgundy, blue and purple to brown. Whole kernel of coloured maize contains many valuable secondary metabolites, such as carotenoids and phenolic compounds, of which phenolic acids and flavonoids represent their predominant form (Simić et al., 2018; Žilić et al., 2012).

The amount and type of plant cell wall material, i.e. lignocellulosic fibres, determines the nutritional quality of the silage maize. The optimum nutritive and fibre composition of maize is essential because differences in silage quality can translate into variations in animal performance. Studies have shown that high cell wall contents, i.e. lignocellulosic fibre of forage maize may limit digestibility and fodder intake of ruminants. Thus, the best estimates of silage maize suitability for ruminant nutrition can be obtained through forage analysis (Kokić et al., 2018; Kruse et al., 2008).

The main objective of this study was to investigate the most important quality parameters of the whole plant of maize hybrids in order to determine their suitability for the preparation of silage for ruminant nutrition. Five commercial yellow kernel dent hybrids and five analogue red kernel hybrids were used in this study to evaluate the agronomic traits, dry matter content of the whole plant, green matter yield, lignocellulosic fibre composition, ratios between different fibres, in vitro dry matter and NDF digestibility (IVDMD and NDFD, respectively), as well as correlation coefficients between the assessed parameters of the whole maize plant.

\section{MATERIALS AND METHODS}

Ten dent maize hybrids with different genetic background and maturity groups, of which five with yellow kernel, and five with red kernel (ZP 366, ZP 388, ZP 4007, ZP 555, ZP 606, ZP 366 red, ZP 388 red, ZP 4007 red, ZP 555 red, and $\mathrm{ZP} 606_{\text {red }}$ ) were tested in the field experiment in 2019.

The field trial was set up according to the randomized complete block design with two replicates in the experimental field of the Maize Research Institute, Zemun Polje, Belgrade, Serbia. The elementary plot size was $21 \mathrm{~m}^{2}$ (consisting of 6 rows with $4.7 \mathrm{~m}$ length) and the sowing density was 60000 plants per hectare. Five average plants from each replication were sampled from two inner rows in the optimal phase of maturity of maize for silage when the dry matter content of the whole plant ranged approximately between 30 and $35 \%$, i.e. between one-quarter and one-half milk-line kernel stages of maturity. Samples of the whole maize plants were first chopped and then dried at 60 ${ }^{\circ} \mathrm{C}$ for $48 \mathrm{~h}$ in a forced-air drying oven until constant moisture was reached and then ground in the mill with 1-mm sieves.

\section{Chemical analyses}

The dry matter content of the whole maize plant as well as the percentage of the stover and ear in the dry matter yield of the whole maize plant were determined. The contents of lignocellulosic fibres: hemicellulose, cellulose, neutral detergent fibre (NDF), acid detergent fibre (ADF), and acid detergent lignin (ADL) were determined by the Van Soest detergent method (1980) modified by Mertens (1992). This method is based on the solubility of fibres in neutral, acid, and alkali reagents. The content of hemicellulose was obtained as a difference between NDF and ADF contents, while the cellulose content was calculated as the difference between ADF and lignin contents. All the results are given as the percentage per dry matter (d.m.). In vitro dry matter digestibility (IVDMD) of the whole maize plant samples 
was performed by the Aufréré method (2007) based on the enzymatic solubility. The in vitro neutral detergent fibre digestibility (NDFD) was calculated as the percent of the NDF that was digested in the in vitro rumen fluid process according to the equation proposed by Barrière et al (2018): IVNDFD=100 x (IVDMD (100 - NDF))/NDF).

\section{Statistical analysis}

Data was analysed in Minitab19 Statistical Software using one-way ANOVA analysis of variance with Fisher's LSD (Least Significance Difference) test. Differences between the means with probability $\mathrm{p}<0.05$ were accepted as statistically significant. The level of confidence was set at $95 \%$. Pearson's, rrelation coefficients were calculated using IBM SPSS Statistica Software Package.

\section{RESULTS AND DISCUSSION}

When developing maize hybrids intended for

Table 1.

Agronomic traits of the studied maize hybrids

\begin{tabular}{|c|c|c|c|c|c|c|}
\hline Hybrid & PH & EH & $\mathbf{E} / \mathbf{P}$ & $\mathbf{L A E}$ & $\mathbf{L W}$ & $\mathbf{L L}$ \\
\hline ZP 366 & $272.88 \pm 10.43^{\mathrm{c}}$ & $87.00 \pm 8.49^{\mathrm{e}}$ & $31.85 \pm 1.89^{\mathrm{c}, \mathrm{d}}$ & $5.48 \pm 0.03^{\mathrm{d}}$ & $9.05 \pm 0.28^{\mathrm{f}}$ & $89.38 \pm 1.17^{\mathrm{c}}$ \\
\hline ZP 388 & $285.88 \pm 2.3^{\mathrm{b}, \mathrm{c}}$ & $101.13 \pm 7.95^{\mathrm{b}, \mathrm{c}, \mathrm{d}, \mathrm{e}}$ & $35.36 \pm 2.50^{\mathrm{b}, \mathrm{c}}$ & $5.80 \pm 0.28^{\mathrm{a}, \mathrm{b}, \mathrm{c}, \mathrm{d}}$ & $9.20 \pm 0.07^{\mathrm{e}, \mathrm{f}}$ & $90.58 \pm 1.45^{b, c}$ \\
\hline ZP 4007 & $296.13 \pm 3.71^{\mathrm{a}, \mathrm{b}}$ & $92.88 \pm 0.18^{\mathrm{c}, \mathrm{d}, \mathrm{e}}$ & $31.37 \pm 0.45^{\mathrm{c}, \mathrm{d}}$ & $5.58 \pm 0.18^{\mathrm{c}, \mathrm{d}}$ & $9.48 \pm 0.03^{\mathrm{c}, \mathrm{d}, \mathrm{e}}$ & $90.95 \pm 2.55^{b, c}$ \\
\hline ZP 555 & $299.88 \pm 4.07^{\mathrm{a}}$ & $103.50 \pm 4.24^{\mathrm{b}, \mathrm{c}, \mathrm{d}}$ & $34.51 \pm 0.95^{\mathrm{b}, \mathrm{c}, \mathrm{d}}$ & $5.98 \pm 0.11^{\mathrm{a}, \mathrm{b}}$ & $10.55 \pm 0.14^{\mathrm{a}}$ & $94.48 \pm 2.02^{\mathrm{b}, \mathrm{c}}$ \\
\hline ZP 606 & $291.88 \pm 9.02^{\mathrm{a}, \mathrm{b}}$ & $110.00 \pm 2.12^{\mathrm{a}, \mathrm{b}}$ & $37.72 \pm 1.89^{\mathrm{a}, \mathrm{b}}$ & $5.90 \pm 0.21^{\mathrm{a}, \mathrm{b}, \mathrm{c}}$ & $9.75 \pm 0.07^{\mathrm{c}, \mathrm{d}}$ & $96.43 \pm 3.78^{\mathrm{a}}$ \\
\hline ZP 366 red & $291.88 \pm 7.95^{\mathrm{a}, \mathrm{b}}$ & $103.75 \pm 15.6^{\mathrm{b}, \mathrm{c}}$ & $35.49 \pm 4.36^{\mathrm{b}, \mathrm{c}}$ & $5.70 \pm 0.21^{\mathrm{b}, \mathrm{c}, \mathrm{d}}$ & $9.07 \pm 0.09^{\mathrm{f}}$ & $96.78 \pm 2.09^{\mathrm{a}}$ \\
\hline ZP 388 $8_{\text {red }}$ & $285.13 \pm 6.89^{b, c}$ & $106.13 \pm 5.48^{\mathrm{a}, \mathrm{b}, \mathrm{c}}$ & $37.21 \pm 1.02^{\mathrm{a}, \mathrm{b}}$ & $5.83 \pm 0.03^{\mathrm{a}, \mathrm{b}, \mathrm{c}, \mathrm{d}}$ & $9.80 \pm 0.28^{\mathrm{b}, \mathrm{c}}$ & $91.05 \pm 1.70^{\mathrm{b}, \mathrm{c}}$ \\
\hline $\mathrm{ZP} 4007_{\text {red }}$ & $288.60 \pm 1.20^{\mathrm{a}, \mathrm{b}}$ & $88.93 \pm 1.67^{\mathrm{d}, \mathrm{e}}$ & $30.81 \pm 0.45^{\mathrm{d}}$ & $5.72 \pm 0.11^{\mathrm{b}, \mathrm{c}, \mathrm{d}}$ & $9.42 \pm 0.11^{\mathrm{d}, \mathrm{e}}$ & $89.13 \pm 1.53^{\mathrm{c}}$ \\
\hline ZP $555_{\text {red }}$ & $287.38 \pm 3.01^{\mathrm{a}, \mathrm{b}}$ & $109.13 \pm 1.94^{\mathrm{a}, \mathrm{b}}$ & $37.98 \pm 1.07^{\mathrm{a}, \mathrm{b}}$ & $5.63 \pm 0.25^{\mathrm{b}, \mathrm{c}, \mathrm{d}}$ & $10.15 \pm 0.21^{b}$ & $92.28 \pm 3.08^{a, b, c}$ \\
\hline ZP 606 red & $296.38 \pm 6.54^{\mathrm{a}, \mathrm{b}}$ & $120.88 \pm 2.3^{\mathrm{a}}$ & $40.80 \pm 1.68^{\mathrm{a}}$ & $6.15 \pm 0.07^{\mathrm{a}}$ & $10.55 \pm 0.07^{\mathrm{a}}$ & $96.33 \pm 1.87^{\mathrm{a}}$ \\
\hline
\end{tabular}

\section{Table 2.}

Dry matter content of the whole plant and share of ear and stover in the harvested plants calculated on d.m content

\begin{tabular}{lccc}
\hline \multirow{2}{*}{ Hybrid } & & \multicolumn{2}{c}{$\begin{array}{c}\text { Dry matter share per part of the } \\
\text { plant (\%) }\end{array}$} \\
\cline { 3 - 4 } & Dry matter content (\%) & Ear & Stover \\
\hline ZP 366 & $38.74 \pm 0.13^{\mathrm{a}}$ & $53.01 \pm 1.18^{\mathrm{a}, \mathrm{b}}$ & $47.06 \pm 0.00^{\mathrm{a}, \mathrm{b}}$ \\
ZP 388 & $35.90 \pm 0.45^{\mathrm{c}}$ & $53.98 \pm 0.21^{\mathrm{a}}$ & $41.70 \pm 4.67^{\mathrm{b}, \mathrm{c}}$ \\
ZP 4007 & $35.67 \pm 0.96^{\mathrm{c}}$ & $49.45 \pm 1.19^{\mathrm{d}}$ & $44.12 \pm 4.16^{\mathrm{a}, \mathrm{b}, \mathrm{c}}$ \\
ZP 555 & $36.51 \pm 1.50^{\mathrm{c}, \mathrm{d}}$ & $50.60 \pm 0.48^{\mathrm{c}, \mathrm{d}}$ & $48.53 \pm 2.08^{\mathrm{a}}$ \\
ZP 606 & $35.09 \pm 1.08^{\mathrm{c}}$ & $51.47 \pm 1.46^{\mathrm{b}, \mathrm{c}, \mathrm{d}}$ & $49.72 \pm 3.76^{\mathrm{a}}$ \\
ZP 366 & $35.67 \pm 1.09^{\mathrm{c}}$ & $52.58 \pm 1.80^{\mathrm{a}, \mathrm{b}, \mathrm{c}}$ & $47.06 \pm 0.00^{\mathrm{a}, \mathrm{b}}$ \\
ZP 388 & $36.33 \pm 0.59^{\mathrm{b}, \mathrm{c}}$ & $52.70 \pm 0.42^{\mathrm{a}, \mathrm{b}, \mathrm{c}}$ & $41.83 \pm 0.92^{\mathrm{b}, \mathrm{c}}$ \\
ZP 4007 & $38.03 \pm 0.45^{\mathrm{a}, \mathrm{b}}$ & $52.35 \pm 0.01^{\mathrm{a}, \mathrm{b}, \mathrm{c}}$ & $39.34 \pm 2.60^{\mathrm{c}}$ \\
ZP 555 & $49.36 \pm 1.09^{\mathrm{d}}$ & $42.47 \pm 1.82^{\mathrm{b}, \mathrm{c}}$ \\
ZP 606 & $36.38 \pm 0.12^{\mathrm{b}, \mathrm{c}}$ & $53.13 \pm 0.50^{\mathrm{a}, \mathrm{b}}$ & $46.41 \pm 0.93^{\mathrm{a}, \mathrm{b}}$ \\
\hline Results are given as mean \pm standard deviation. Means that do not share a letter are significantly different
\end{tabular}

silage production, enhanced yield and nutritional value are of great importance. Plant height is one of the most important agronomic traits of maize that positively influences higher grain yields because. Taller healthy plants with more ears can lead to additional biomass and grain yield (Khan et al., 2019; Crevelari et al., 2018). Plant height varied among the hybrids from $272.88 \mathrm{~cm}$ (ZP 366) to $299.88 \mathrm{~cm}$ (ZP $555)$, however, no major differences regarding plant height, nor other agronomic traits such as ear height, ear to plant ratio, leaf width and leaf length were noticed between yellow and red kernel genotypes (Table 1). Results in table 2 represent the dry matter content of the whole maize plant as well as the share of the stover and ear in the dry matter yield of the whole maize plant of the investigated maize genotypes. The dry matter content of the whole plant ranged from $33.76 \pm 0.67 \%$ (ZP $606_{\text {red }}$ ) to $38.74 \pm 0.13 \%$ (ZP 366). Stover and ear contribute to the final forage dry matter yield after 
the maize plant is harvested, therefore,both components must be considered. The yellow kernel hybrid ZP 388 had the highest share of ear $(53.98 \pm 0.21 \%)$, and the lowest $(49.36 \pm 1.09 \%)$ ear percentage was detected in the red kernel hybrid ZP $555_{\text {red. }}$.

The content of lignocellulosic fibres is one of the most important indicators of the nutritional value and technological quality of maize biomass intended for ruminant nutrition (Terzić et al., 2020). The NDF fraction consists of cell wall material that includes cellulose, hemicellulose, lignin and silica. Lignin is important from a nutritional point of view because it is completely indigestible and its presence reduces the availability of the cellulose and hemicellulose parts of the silage. However, even though it can be a negative indicator of silage quality, NDF is also required by ruminant animals. Acid detergent fibre (ADF) mainly consists of cellulose, indigestible lignin and inorganic silica and is negatively correlated with digestibility of forages (Bittman, 2004). As the portion of NDF increases in with the advancing maturity of the maize plant, animals tend to consume less forage. The variation of whole plant contents of lignocellulosic fractions reflects the changes in the proportions of plant organs and in their respective ratios of cell wall and cell content. As a result of starch accumulation in the ear, the whole-crop fibre content decreases with time, which overcompensates for the rise in stover cell wall content (Kruse et al., 2008). The NDF content of the whole plant ranged from $41.98 \%$ (ZP 555) to $46.33 \%$ (ZP 366 $6_{\text {red }}$ ); ADF from 20.48\% (ZP 555 ) to $23.60 \%$ (ZP 4007 red); ADL from $1.70 \%$ (ZP 555 red ) to $2.89 \%$ (ZP 606); hemicellulose from $20.59 \%$ (ZP 606) to $24.07 \%$ (ZP 606 $6_{\text {red }}$ ), and cellulose from $17.86 \%$ (ZP 555) to $20.92 \%$ (ZP 4007 $7_{\text {red }}$ ), respectively (Table 3).

Table 3.

Lignocellulosic fibres content of the whole plant of maize hybrids

\begin{tabular}{lccccc}
\hline Hybrid & NDF (\%) & ADF (\%) & ADL (\%) & Hemicellulose (\%) & Cellulose (\%) \\
\hline ZP 366 & $42.76 \pm 0.14^{\mathrm{a}, \mathrm{b}}$ & $20.67 \pm 0.22^{\mathrm{b}}$ & $2.39 \pm 0.21^{\mathrm{a}}$ & $22.10 \pm 0.08^{\mathrm{b}, \mathrm{c}}$ & $18.28 \pm 0.01^{\mathrm{b}, \mathrm{c}}$ \\
ZP 388 & $42.80 \pm 0.91^{\mathrm{a}, \mathrm{b}}$ & $21.12 \pm 0.51^{\mathrm{a}, \mathrm{b}}$ & $2.44 \pm 0.02^{\mathrm{a}}$ & $21.68 \pm 0.40^{\mathrm{b}, \mathrm{c}}$ & $18.69 \pm 0.53^{\mathrm{a}, \mathrm{b}, \mathrm{c}}$ \\
ZP 4007 & $45.65 \pm 2.80^{\mathrm{a}}$ & $23.55 \pm 1.20^{\mathrm{a}}$ & $2.78 \pm 0.08^{\mathrm{a}}$ & $22.10 \pm 1.60^{\mathrm{b}, \mathrm{c}}$ & $20.77 \pm 1.12^{\mathrm{a}, \mathrm{b}}$ \\
ZP 555 & $41.98 \pm 0.05^{\mathrm{b}}$ & $20.48 \pm 0.70^{\mathrm{b}}$ & $2.62 \pm 0.06 \mathrm{a}$ & $21.51 \pm 0.65^{\mathrm{b}, \mathrm{c}}$ & $17.86 \pm 0.64^{\mathrm{c}}$ \\
ZP 606 & $42.70 \pm 0.00^{\mathrm{a}, \mathrm{b}}$ & $22.12 \pm 1.01^{\mathrm{a}, \mathrm{b}}$ & $2.89 \pm 0.03^{\mathrm{a}}$ & $20.59 \pm 1.01^{\mathrm{a}}$ & $19.23 \pm 0.98^{\mathrm{a}, \mathrm{b}, \mathrm{c}}$ \\
ZP 366 $_{\text {red }}$ & $46.33 \pm 3.71^{\mathrm{a}}$ & $23.42 \pm 3.18^{\mathrm{a}}$ & $2.59 \pm 0.30^{\mathrm{a}}$ & $22.91 \pm 0.53^{\mathrm{a}, \mathrm{b}}$ & $20.84 \pm 2.90^{\mathrm{a}}$ \\
ZP 388 $_{\text {red }}$ & $45.47 \pm 1.73^{\mathrm{a}, \mathrm{b}}$ & $23.08 \pm 0.77^{\mathrm{a}, \mathrm{b}}$ & $2.82 \pm 0.12^{\mathrm{a}}$ & $22.39 \pm 0.96^{\mathrm{a}, \mathrm{b}}$ & $20.46 \pm 0.89^{\mathrm{a}, \mathrm{b}}$ \\
ZP 4007 $_{\text {red }}$ & $46.18 \pm 0.03^{\mathrm{a}}$ & $23.60 \pm 0.65^{\mathrm{a}}$ & $2.69 \pm 0.64^{\mathrm{a}}$ & $22.58 \pm 0.68^{\mathrm{a}, \mathrm{b}}$ & $20.92 \pm 0.01^{\mathrm{a}}$ \\
ZP 555 red $_{\text {ZP 606 }}$ & $42.82 \pm 0.00^{\mathrm{a}, \mathrm{b}}$ & $21.39 \pm 0.47^{\mathrm{a}, \mathrm{b}}$ & $1.70 \pm 0.11^{\mathrm{b}}$ & $21.43 \pm 0.47^{\mathrm{b}, \mathrm{c}}$ & $19.70 \pm 0.36^{\mathrm{a}, \mathrm{b}, \mathrm{c}}$ \\
\hline
\end{tabular}

Results are given as mean \pm standard deviation. Means that do not share a letter are significantly different

Table 4.

Average ratios of the lignocellulosic fibres of the whole hybrid maize plants

\begin{tabular}{lccccccc}
\hline Hybrid & $\begin{array}{c}\text { ADL/ } \\
\text { NDF }\end{array}$ & $\begin{array}{c}\text { ADL/ } \\
\text { ADF }\end{array}$ & $\begin{array}{c}\text { ADF/ } \\
\text { NDF }\end{array}$ & $\begin{array}{c}\text { Hemicellulose/ } \\
\text { NDF }\end{array}$ & $\begin{array}{c}\text { Cellulose/ } \\
\text { NDF }\end{array}$ & $\begin{array}{c}\text { Cellulose/ } \\
\text { Hemicellulose }\end{array}$ & $\begin{array}{c}\text { Hemicellulose/ } \\
\text { Cellulose }\end{array}$ \\
\hline ZP 366 & 5.59 & 11.56 & 48.34 & 51.68 & 42.75 & 82.71 & 120.90 \\
ZP 388 & 5.70 & 11.55 & 49.35 & 50.65 & 43.67 & 86.21 & 116.00 \\
ZP 4007 & 6.09 & 11.80 & 51.59 & 48.41 & 45.65 & 93.98 & 106.40 \\
ZP 555 & 6.24 & 12.79 & 48.79 & 51.24 & 42.54 & 83.03 & 120.44 \\
ZP 606 & 6.77 & 13.07 & 51.80 & 48.22 & 45.04 & 93.39 & 107.07 \\
ZP 366 & 5.59 & 11.06 & 50.56 & 49.46 & 44.99 & 90.96 & 109.93 \\
ZP 388 & 5.76 & 11.35 & 50.77 & 49.25 & 45.01 & 91.38 & 109.43 \\
ZP 4007 & 5.83 & 11.40 & 51.10 & 48.90 & 45.30 & 92.65 & 107.94 \\
ZP 555 red & 3.97 & 7.95 & 49.95 & 50.05 & 46.01 & 91.93 & 108.78 \\
ZP 606 & 3.88 & 8.23 & 47.19 & 52.83 & 43.31 & 81.97 & 122.00 \\
\hline Min & 3.88 & 7.95 & 47.19 & 48.22 & 42.54 & 81.97 & 106.40 \\
Max & 6.77 & 13.07 & 51.80 & 52.83 & 46.01 & 93.98 & 122.00 \\
Mean & 5.54 & 11.08 & 49.94 & 50.07 & 44.43 & 88.82 & 112.89 \\
SD & 0.92 & 1.70 & 1.51 & 1.51 & 1.25 & 4.80 & 6.25 \\
\hline
\end{tabular}




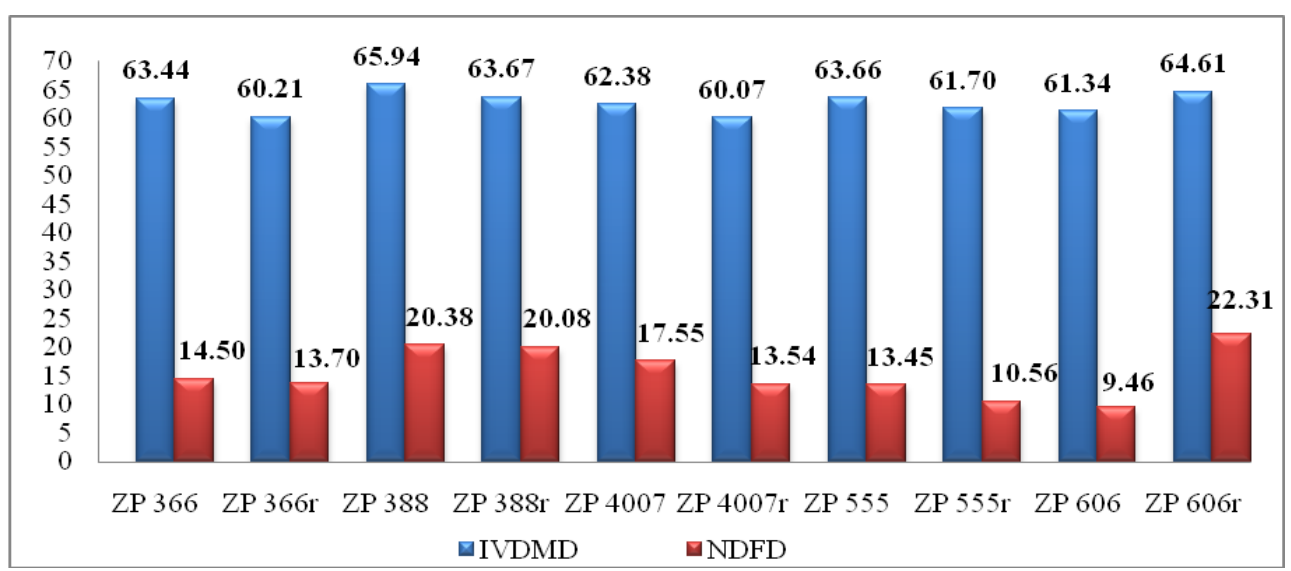

Figure 1. IVDMD and NDFD of the investigated maize hybrids (\%)

The average ratios of individual lignocellulosic fibres of the whole maize plant: ADL/NDF, ADL/ADF, ADF/NDF, hemicellulose/NDF, cellulose/NDF, cellulose/hemicellulose, hemicellulose/cellulose varied as followed: $3.88-$ $6.77 \%, 7.95-13.07 \%, 47.19-51.80 \%$, 48.22$52.83 \%, 42.54-46.01 \%, 81.97-93.98 \%$ and 106.40-122.00\%, respectively (Table 4). These results are in accordance with those of studies previously reported by Khan et al. (2015), Milašinović-Šeremešić et al. (2017) and Semenčenko et al. (2016).

Since the digestibility of parts of the maize plant varies from hybrid to hybrid, the quality of maize hybrids is determined by the morphology and structure of the plant (Bertoia \& $\mathrm{Au}-$ licino, 2014). Results of a study conducted by Barrière et al. (2005) showed that modern hybrids on average have $5.5 \%$ lower in vivo digestibility of the cell wall than old hybrids, despite a slight but significant increase in grain content in the whole maize plant. However, the degree of lignification of cell wall constituents is a limiting factor for silage digestibility. Recent studies have also indicated that rumen digestibility of maize crop varies according to genetic differences among the maize hybrids (Crevelari et al., 2018). In recent years, in addition to the content of lignocellulosic fractions, some researchers started using the NDF digestibility as quality parameters of fibrous feeds. The lower NDF digestibility is the indicator of lower dry matter digestibility, and thus the energy value of feed is lower and production performance (meat and milk) of animals is lower (Milašinović-Šeremešić et al., 2017). Among the analysed hybrids, the lowest in vitro dry matter digestibility of the whole maize plant $(60.07 \%)$ was determined in the red kernel hybrid ZP 4007 red (Figure 1), which may have been caused by high lignin content (Table 3 ). The highest IVDMD obtained by the yellow kernel genotype ZP 388 (65.94\%, Figure 1). Negative correlation was determined between the IVDMD and ADF/NDF ratio ($0.63^{*}$, Table 6). Significantly high positive correlation was determined between IVDMD and cellulose/hemicellulose ratio $\left(0.67^{*}\right)$, as well as IVDMD and NDFD $\left(0.70^{*}\right.$, Table 6$)$.

Although the yellow kernel hybrid ZP 388 had the highest dry matter digestibility (65.94\%), the ZP 606 red hybrid showed the lowest ADL/NDF ratio (3.88\%), and also had high digestibility (64.61\%). The yellow grain hybrid ZP 606 had the highest ADL/NDF ratio $(6.77 \%)$ and the lowest digestibility of the tested yellow kernel hybrids (61.34\%). Hybrids which have high IVDMD due to higher percent of grain because they were harvested more mature can be differentiated from those which have inherently better fibre quality by comparing the NDFD (Moore and Jung, 2001). The results obtained by calculating the NDFD for the whole plant of the tested hybrids are shown in Table 4. The highest NDFD was calculated for hybrid ZP 606 red $(22.32 \%)$, and the lowest for genotype ZP 606 (9.46\%), which is in accordance with the findings of Barrière et al. (2018). The statistically analysed correlation coeffi-cients between agronomic traits of silage maize hybrids (Table 5) showed negative correlation between dry matter content of the whole crop and height of the maize plant $\left(-0.67^{*}\right)$, as well as ear height $\left(-0.84^{* * *}\right)$. The stover share was positively correlated with the leaf length $\left(0.71^{*}\right)$. 
Table 5.

Correlation coefficients between agronomic traits of silage maize hybrids

\begin{tabular}{lccccccccc}
\hline & PH & EH & E/P & LAE & LW & LL & DM & Ear & Stover \\
\hline PH & 1.00 & 0.48 & 0.26 & 0.62 & 0.60 & 0.60 & $-0.67^{*}$ & -0.41 & 0.25 \\
EH & 0.48 & 1.00 & $0.97^{* *}$ & $0.77^{* *}$ & $0.69^{*}$ & $0.76^{*}$ & $-0.84^{* *}$ & 0.02 & 0.30 \\
E/P & 0.26 & $0.97^{* *}$ & 1.00 & $0.68^{*}$ & 0.59 & $0.66^{*}$ & $-0.75^{*}$ & 0.12 & 0.26 \\
LAE & 0.62 & $0.77^{* *}$ & $0.68^{*}$ & 1.00 & $0.72^{*}$ & 0.62 & $-0.68^{*}$ & 0.24 & 0.27 \\
LW & 0.60 & $0.69^{*}$ & 0.59 & $0.72^{*}$ & 1.00 & 0.43 & -0.47 & -0.36 & 0.22 \\
LL & 0.60 & $0.76^{*}$ & $0.66^{*}$ & 0.62 & 0.43 & 1.00 & $-0.75^{*}$ & -0.05 & $0.71^{*}$ \\
DM & $-0.67^{*}$ & $-0.84^{* *}$ & $-0.75^{*}$ & $-0.68^{*}$ & -0.47 & $-0.75^{*}$ & 1.00 & 0.03 & -0.31 \\
Ear & -0.41 & 0.02 & 0.12 & 0.24 & -0.36 & -0.05 & 0.03 & 1.00 & -0.10 \\
Stover & 0.25 & 0.30 & 0.26 & 0.27 & 0.22 & $0.71^{*}$ & -0.31 & -0.10 & 1.00 \\
\hline
\end{tabular}

Table 6.

Correlation coefficients between certain parameters of silage maize quality

\begin{tabular}{|c|c|c|c|c|c|c|c|c|c|c|c|c|c|c|}
\hline & NDF & ADF & ADL & HC & $\mathbf{C}$ & $\begin{array}{l}\text { ADL/ } \\
\text { NDF }\end{array}$ & $\begin{array}{l}\text { ADL/ } \\
\text { ADF }\end{array}$ & $\begin{array}{l}\text { ADF/ } \\
\text { NDF }\end{array}$ & $\begin{array}{l}\mathrm{HC} / \\
\mathrm{NDF}\end{array}$ & $\begin{array}{c}\mathrm{C} / \\
\mathrm{NDF}\end{array}$ & $\begin{array}{c}\mathrm{HC} / \\
\mathrm{C}\end{array}$ & $\mathrm{C} / \mathrm{HC}$ & $\begin{array}{c}\text { IVDM } \\
\text { D }\end{array}$ & $\begin{array}{c}\text { NDF } \\
\text { D }\end{array}$ \\
\hline $\mathrm{NDF}$ & 1.00 & $0.85^{* *}$ & 0.14 & $0.73^{*}$ & $0.90^{* *}$ & -0.14 & -0.22 & 0.26 & -0.26 & 0.44 & 0.37 & -0.37 & -0.39 & 0.39 \\
\hline $\mathrm{ADF}$ & $0.85^{\text {** }}$ & 1.00 & 0.47 & 0.26 & $0.95^{* *}$ & 0.22 & 0.10 & $0.73^{*}$ & $-0.73^{*}$ & $0.74^{*}$ & $0.78^{* *}$ & $-0.78^{* *}$ & -0.62 & 0.04 \\
\hline $\mathrm{ADL}$ & 0.14 & 0.47 & 1.00 & -0.36 & 0.16 & $0.95^{* *}$ & $0.91^{* *}$ & $0.67^{*}$ & $-0.67^{*}$ & 0.11 & 0.42 & -0.42 & -0.25 & -0.14 \\
\hline $\begin{array}{l}\mathrm{HC} \\
\mathrm{C}\end{array}$ & $\begin{array}{l}0.73^{*} \\
0.90^{* *}\end{array}$ & $\begin{array}{c}0.26 \\
0.95^{* *}\end{array}$ & $\begin{array}{c}-0.36 \\
0.16\end{array}$ & $\begin{array}{l}1.00 \\
0.42\end{array}$ & $\begin{array}{l}0.42 \\
1.00\end{array}$ & $\begin{array}{l}-0.55 \\
-0.11\end{array}$ & $\begin{array}{l}-0.52 \\
-0.23\end{array}$ & $\begin{array}{c}-0.47 \\
0.57\end{array}$ & $\begin{array}{c}0.47 \\
-0.57\end{array}$ & $\begin{array}{l}-0.16 \\
0.78^{* *}\end{array}$ & $\begin{array}{l}-0.33 \\
0.71^{*}\end{array}$ & $\begin{array}{c}0.34 \\
-0.71^{*}\end{array}$ & $\begin{array}{c}0.10 \\
-0.58\end{array}$ & $\begin{array}{r}0.66^{*} \\
0.12\end{array}$ \\
\hline $\begin{array}{l}\mathrm{ADL} / \mathrm{N} \\
\mathrm{DF}\end{array}$ & -0.14 & 0.22 & $0.95^{* *}$ & -0.55 & -0.11 & 1.00 & $0.99^{* *}$ & 0.58 & -0.58 & -0.03 & 0.30 & -0.30 & -0.18 & -0.28 \\
\hline $\begin{array}{l}\mathrm{ADL} / \mathrm{A} \\
\mathrm{DF}\end{array}$ & -0.22 & 0.10 & $0.91^{* *}$ & -0.52 & -0.23 & $0.99^{* *}$ & 1.00 & 0.45 & -0.44 & -0.19 & 0.14 & -0.14 & -0.08 & -0.24 \\
\hline $\begin{array}{l}\text { ADF/ND } \\
\text { F }\end{array}$ & 0.26 & $0.73^{*}$ & $0.67^{*}$ & -0.47 & 0.57 & 0.58 & 0.45 & 1.00 & $-1.00^{* *}$ & $0.79^{* *}$ & $0.95^{* *}$ & $-0.95^{* *}$ & $-0.63^{*}$ & -0.42 \\
\hline $\mathrm{HC} / \mathrm{NDF}$ & -0.26 & $-0.73^{*}$ & $-0.67^{*}$ & 0.47 & -0.57 & -0.58 & -0.44 & $-1.00^{* *}$ & 1.00 & $-0.80^{* *}$ & $0.95^{* * *}$ & $0.95^{* *}$ & 0.63 & 0.42 \\
\hline $\mathrm{C} / \mathrm{NDF}$ & 0.44 & $0.74^{*}$ & 0.11 & -0.16 & $0.78^{* *}$ & -0.03 & -0.19 & $0.79^{* *}$ & $-0.80^{* *}$ & 1.00 & $0.94^{* *}$ & $-0.94^{* *}$ & $-0.64^{*}$ & -0.30 \\
\hline $\mathrm{C} / \mathrm{HC}$ & 0.37 & $0.78^{* *}$ & 0.42 & -0.33 & $0.71^{*}$ & 0.30 & 0.14 & $0.95^{* *}$ & $-.95^{* *}$ & $.94^{* *}$ & 1.00 & $-1.00^{* *}$ & $-0.68^{*}$ & -0.39 \\
\hline $\mathrm{HC} / \mathrm{C}$ & -0.37 & $-0.76^{* *}$ & -0.42 & 0.34 & $-0.71^{*}$ & -0.30 & -0.14 & $-0.95^{* *}$ & $.95^{* *}$ & $-.94^{* *}$ & $1.00^{* *}$ & 1.00 & $.670^{*}$ & 0.39 \\
\hline IVDMD & -0.39 & -0.62 & -0.25 & 0.10 & -0.58 & -0.18 & -0.08 & $-0.63^{*}$ & 0.63 & $-0.64^{*}$ & $-0.68^{*}$ & $0.67^{*}$ & 1.00 & $0.70^{*}$ \\
\hline NDFD & 0.39 & 0.04 & -0.14 & $0.66^{*}$ & 0.12 & -0.28 & -0.24 & -0.42 & 0.42 & -0.30 & -0.39 & 0.39 & $0.70^{*}$ & 1.00 \\
\hline
\end{tabular}

* Correlation is significant at the 0.05 level. **Correlation is significant at the 0.01 level. HC-hemicellulose; C-cellulose

Insignificant differences between fibre composition, agronomic traits as well as IVDMD and NDFD of yellow and red kernel hybrids can be attributed to the fact that red kernel hybrids were created by breeding from the analogue yellow kernel lines, and therefore inherited most of their parental properties.

\section{CONCLUSIONS}

The content of individual lignocellulosic fibres did not significantly influence the IVDMD, however negative correlation was determined between the IVDMD and ADF/NDF ratio ($\left.0.63^{*}\right)$. Significantly high positive correlation was determined between the IVDMD and cellulose/hemicellulose ratio $\left(0.67^{*}\right)$, as well as IVDMD and NDFD $\left(0.70^{*}\right)$. Regarding the IVDMD, the hybrids ZP 388 and ZP 606 were superior to other investigated hybrids. Even though the results of our study showed significant variations in nutritional composition of the whole maize plant (i.e. in the content of lignocellulosic fibres and in vitro dry matter digestibility), the hybrid and the differrences in kernel colour (yellow or red) did not considerably affect the quality of the maize hybrids for silage production. The highest IVDMD was determined in yellow kernel hybrid ZP 388, while the maximum NDFD were observed in the red kernel hybrid ZP $606_{\text {red }}$ which also showed the lowest ADL/NDF and $\mathrm{ADF} / \mathrm{NDF}$ ratios.

The results indicate that all of the hybrids used in this study are good candidates for the production of high quality silage for ruminant nutrition. The results obtained in this study could be of exceptional importance for the breeding programs and selection of potentially most suitable hybrids for silage production. 


\section{ACKNOWLEDGEMENTS}

This study was supported by the Ministry of Education, Science and Technological Development of the Republic of Serbia.

\section{REFERENCES}

Aufrere, J., Baumont, R., Delaby, L., Peccatte, J.-R., Andrieu, J., Andrieu, J.-P., \& Dulphy J.-P. (2007). Prevision de la digestibilite des fourages par la méthode pepsine-cellulase. Le point sur les équations proposées. INRA Productions Animales 20, 129-136. https://doi.org/10.20870/productionsanimales.2007.20.2.3445

Barrière, Y., Alber, D., Dolstra, O., Lapierre, C., Motto, M., Ordas, A., Van Waes, J., Vlasminkel, L., Welcker, C., \& Monod, J. P. (2005). Past and prospects of forage maize breeding in Europe: I. The grass cell wall as basis of genetic variation and future improvements in feeding value. Maydica, 50, 259-274. Retrieved from http://hdl.handle.net/10261/42856

Barrière, Y., Guillaumie, S., Denoue, D., Pichon, M., Goffner, D., \& Martinant, J. (2018). Investigating the unusually high cell wall digestibility of the old INRA early flint F4 maize inbred line. Maydica, $62(3), 21$. Retrieved from https://journalscrea.4science.it/index.php/maydica/article/view/15 81

Bertoia, L. M., \& Aulicino, M. B. (2014). Maize forage aptitude: Combining ability of inbred lines and stability of hybrids. The Crop Journal, 2, 407-418. https://doi.org/10.1016/j.cj.2014.07.002

Bittman, S. (2004). A production guide for coastal British Columbia and the Pacific Northwest. Quality of corn silage (Chapter 8). In Shabtai Bittman \& C. Grant Kowalenko (Eds.), Advanced silage corn management. Agassiz: Pacific Field Corn Association.

Crevelari, J. A., Durães, N. N. L., Bendia, L. C. R., da Silva, A. J., Azevedo, F. H. V., Azeredo, V. C., \& Pereira, M. G. (2018). Assessment of agronomic performance and prediction of genetic gains through selection indices in silage corn. Australian Journal of Crop Science, 12(5), 800-807. https://doi.org/10.21475/ajcs.18.12.05.PNE1004

Eckhoff, S. R., \& Watson, S. A. (2009). Corn and sorghum starches: Production. In J. N. BeMiller \& R. L. Whistler (Eds.), Starch: Chemistry and technology ( $3^{\text {rd }}$ ed., pp. 373-439). Academic Press.

Frey, T. J., Coors, J. G., Shaver, R. D., Lauer, J. G., Eilert, D. T., \& Flannery, P. J. (2004). Selection for silage quality in the Wisconsin quality synthetic and related maize populations. Crop Science, 44, $1200-1208$ https://doi.org/10.2135/cropsci2004.1200

Khan, H. Z., Shabir, M. A., Basit, A., Iqbal, A., Rasheed, A., Saleem, M. F., \& Shabir, K. (2019). Comparative study of different agronomic traits of maize (Zea mays L.) genotypes. Journal of Agriculture and Basic Sciences, 4(1), 18-26. (ISSN Online: 2518-4210) http://www.jabsjournal.com
Khan, N. A., Peiqiang, Y., Ali, M., Cone, J. W., \& Hendriks, W. H. (2015). Nutritive value of maize silage in relation to dairy cow performance and milk quality. Journal of the Science of Food and Agriculture, 95, 238-252. https://doi.org/10.1002/jsfa.6703

Kokić, B. M., Dokić, L. P., Čolović, R. R., Banjac, V. V., Jovanović, R. D., Popović, S. J., \& Lazarević, J. M. (2018). The possibility of in vitro multi-enzymatic method application for the assessment of the influence of thermal treatments on organic matter digestibility of feed for ruminants. Food and Feed Research, 45(1), 53-58. https://doi.org/10.5937/FFR1801053K

Kruse, S., Herrmann, A., Kornher, A., \& Taube, F. (2008). Evaluation of genotype and environmental variation in fibre content of silage maize using a model-assisted approach. European Journal of Agronomy 28, 210-223.

https://doi.org/10.1016/j.eja.2007.07.007

Liu, J., Fernie, A. R., \& Yan, J. (2020). The past, present, and future of maize improvement: Domestication, genomics, and functional genomic routes toward crop enhancement. Plant Сommunications, 1(1), Article 10010, 1-19. https://doi.org/10.1016/j.xplc.2019.100010

Mertens, D. R. (1992). Critical conditions in determining detergent fiber. In Proceedings of the Forage Analysis Workshop (pp. C1-C8). Denver, Colorado. Omaha, NE: National Forage Testing Association.

Milašinović Šeremešić, M. S., Radosavljević, M. M., Srdić, J. Ž., Tomičić, Z. M., \& Đuragić, O. M. (2012). Physical traits and nutritional quality of selected Serbian maize genotypes differing in kernel hardness and colour. Food and Feed Research, 46, 51-59. https://doi.org/10.5937/FFR1901051M

Milašinović-Šeremešić, M., Radosavljević, M., Terzić, D., \& Nikolić, V. (2017). The utilisable value of the maize plant (biomass) for silage. Journal on Processing and Energy in Agriculture, 21, 86-90. https://doi.org/10.5937/JPEA1702086S

Moore, K. J., \& Jung, H.-J. G. (2001). Lignin and fiber digestion. Journal of Range Management, 54, 420430.

https://doi.org/10.2458/azu_jrm_v54i4_moore

Semenčenko, V., Milašinović-Šeremešić, M., Radosavljević, M., Terzić, D., Srdić, J., \& Filipović, M. (2016). Potentials of ZP maize hybrids for silage production. In Proceeedings of XVII International Feed Technology Symposium and the III International Congress "Food Technology Quality and Safety" - FoodTech 2016 (pp. 119-124). Novi Sad, Serbia.

Simić, M., Žilić, S., Šimurina O., Filipčev, B., Škrobot, D., \& Vančetović, J. (2018). Effects of anthocyanin-rich popping maize flour on the phenolic profile and the antioxidant capacity of mix-bread and its physical and sensory properties. Polish Journal of Food and Nutrition Sciences, 68(4), 299-308. https://doi.org/10.2478/pjfns-2018-0002

Sutch, R. (2011). The impact of the 1936 Corn Belt Drought on American farmers' adoption of hybrid corn. In G. D. Libecap \& R. H. Steckel (Eds.), The 
economics of climate change: Adaptations past and present (pp. 195 - 223). Chicago: University of Chicago Press.

Terzić, D., Radosavljević, M., Milašinović-Šeremešić, M., Jovanović, Ž., \& Nikolić, V., (2020). Yield and biomass quality of the whole plant of four maize hybrids for silage production. Journal on Processing and Energy in Agriculture, 24, 6-8. https://doi.org/10.5937/jpea24-25502

Van Soest, P.J., \& Robertson, J. B. (1980). System of analysis for evaluating fibrous feeds. In W. J. Pigden, C. C. Balch \& M. Graham (Eds.), Standardization of analytical methodology in feeds (pp. 4960). Ottawa, Canada: International Re-search Development Center.

Žilić, S., Serpen, A., Akillioğlu, G., Gökmen, V., \& Vančetović, J. (2012). Phenolic compounds, carotenoids, anthocyanins, and antioxidant capacity of colored maize (Zea mays L.) kernels. Journal of Agricultural and Food Chemistry, 60, 1224-1231. https://doi.org/10.1021/jf204367 


\section{СВОЈСТВА РАЗЛИЧИТИХ СИЛАЖНИХ ХИБРИДА КУКУРУЗА}

Валентина В. Николић, Слађана М. Жилић, Милица М. Радосављевић, Јелена П. Ванчетовић, Софија С. Божиновић

Институт за кукуруз, Земун Поље, 11085 Београд-Земун, Слободана Бајића 1, Србија

Сажетак: Циљ овог истраживања био је да се испитају особине десет хибрида кукуруза из Србије укључујући агрономска својства, састав лигноцелулозних влакана и in vitro сварљивост суве материје. Пет хибрида зубана жутог зрна и пет аналогних хибрида црвеног зрна коришћени су у овом истраживању како би се испитала агрономска својства, садржај суве материје целе биљке, садржај лигноцелулозних влакана, односи између појединих лигноцелулозних фракција, in vitro сварљивост суве материје и сварљивости NDF-a. Одређени су коефицијенти корелације између појединих особина хибрида кукуруза. Иако су резултати истраживања показали варијације у погледу нутритивног састава целе биљке кукуруза између испитиваних хибрида, сам хибрид и разлике у боји зрна (жута или црвена) нису значајно утицали на квалитет хибрида кукуруза за производњу силаже. Највиша IVDMD је одређена у хибриду жутог зрна ZP 388, док је хибрид црвеног зрна ZP 606 red имао највиши NDFD, као и најниже односе фракција $\mathrm{ADL} / \mathrm{NDF}$ и ADF/NDF. Резултати указују да сви хибриди из овог истраживања представљају одличне кандидате за производњу квалитетне силаже за исхрану преживара.

Кључне речи: хибриди кукуруза, лигночелулозна влакна, in vitro сварљивост суве мamepuje

Received: 04 November 2020/Received in revised form: 17 November 2020/Accepted: 24 November 2020

Available online: December 2020

This is an open-access article under the CC BY license (http://creativecommons.org/licenses/by/3.0). 